\title{
ICT4D 3.0? Part 1-The components of an emerging "digital-for-development" paradigm
}

DOI:

10.1002/isd2.12124

\section{Document Version}

Final published version

Link to publication record in Manchester Research Explorer

\section{Citation for published version (APA):}

Heeks, R. (2020). ICT4D 3.0? Part 1-The components of an emerging "digital-for-development" paradigm.

Electronic Journal of Information Systems in Developing Countries, [e12124]. https://doi.org/10.1002/isd2.12124

\section{Published in:}

Electronic Journal of Information Systems in Developing Countries

\section{Citing this paper}

Please note that where the full-text provided on Manchester Research Explorer is the Author Accepted Manuscript or Proof version this may differ from the final Published version. If citing, it is advised that you check and use the publisher's definitive version.

\section{General rights}

Copyright and moral rights for the publications made accessible in the Research Explorer are retained by the authors and/or other copyright owners and it is a condition of accessing publications that users recognise and abide by the legal requirements associated with these rights.

\section{Takedown policy}

If you believe that this document breaches copyright please refer to the University of Manchester's Takedown Procedures [http://man.ac.uk/04Y6Bo] or contact uml.scholarlycommunications@manchester.ac.uk providing relevant details, so we can investigate your claim.

\section{OPEN ACCESS}




\title{
ICT4D 3.0? Part 1-The components of an emerging "digital- for-development" paradigm
}

\author{
Richard Heeks
}

Centre for Development Informatics, GDI, University of Manchester, Manchester, UK

Correspondence

Richard Heeks, Centre for Development Informatics, GDI, University of Manchester, Manchester, UK.

Email: richard.heeks@manchester.ac.uk

\begin{abstract}
What has changed in the decade or so since the ideas of a new "ICT4D 2.0" phase were first mooted? This paper reviews those changes, based on a new framework model. At a foundational level, it looks at recent and current trends in digital technologies, data, processes and the implications these have for the user demographics and network structures that underpin the role of digital ICTs in international development. It then summarises some of the new building blocks of development: digital roles, digital products and digital business models. We could call what is emerging "ICT4D 3.0." However, this paper argues that the changes are such that we could talk of a paradigmatic shift and suggests that the elements could be collated as a new "digital-for-development" paradigm. Part 2 of this paper explores the patterns of change in the economy and in politics that may be associated with this paradigm.
\end{abstract}

\section{KEYWORDS}

digital-for-development, ICT4D, paradigm, trends

\section{1 | INTRODUCTION}

The relationship between information and communication technologies (ICTs) and development is constantly evolving. In 2009 , I summarised that evolving relationship in terms of three phases: ICT4D 0.0, ICT4D 1.0 and ICT4D 2.0 (see Table 1 from Heeks (2009)).

The question then arises: in the decade since the idea of ICT4D 2.0 was first promoted, what has changed? In particular, has so much changed that we might demarcate something called "ICT4D 3.0"? Addressing that question is the purpose of this paper and its companion paper that looks at broader patterns in the relation between ICTs and development. Identifying the patterns of changes will help us understand not just what has happened within ICT4D in the past decade but also the current and future trajectory. Such a "big picture" view can provide strategic insight to assist policy, practice and research in the domain.

One element that has changed is our understanding of development. ICT4D 1.0 and 2.0 were both significantly shaped by the Millennium Development Goals (MDGs). The MDGs completed their term in office at the end of 2015 and were replaced by the Sustainable Development Goals. These can be analysed to identify the changing patterns of development priorities, with three core themes emerging (Heeks, 2014a; Heeks, 2014c) ${ }^{1}$ :

- Transformation: "a belief that the incremental developmental changes achieved to date will no longer be sufficient in the remainder of the 21 st century; and an aspiration for a step-change in approach" (ibid.:27).

${ }^{1}$ In addition, the universalisation of development goals is changing the terminology and geography of development from "international development" to "global development" (Horner \& Hulme, 2019). The North-South binary of so-called developed and developing countries is dissolving in favour of a greater focus on divergences within nations, and a recognition that development occurs and is needed everywhere. Having said that, the focus in this paper will remain on developing countries: those in the OECD Development Assistance Committee list of official development aid recipients. 
TABLE 1 Summary of ICT4D phases

\begin{tabular}{|llll|}
\hline Issue/phase & ICT4D 0.0 (1960s-mid-1990s) & ICT4D 1.0 (mid-1990s-mid-/late-2000s) & ICT4D 2.0 (mid-/late-2000s onwards) \\
\hline Iconic technology & PC database & Telecentre & Mobile phone \\
\hline Key application & Data processing & Content ( interaction) \\
\hline The poor & Who? & Consumers & Services \& production \\
\hline Key goal & Organisational efficiency & MDGs \\
\hline Key issue & Technology's potential & Readiness \& availability \\
\hline Key actor & Government & Donors \& NGOs \\
\hline Attitude & Ignore --> isolate & Idolise --> integrate \\
\hline Innovation model & Northern & Pro-Poor --> para-poor \\
\hline Dominant discipline & Information systems & Informatics/Development Studies \\
\hline Development paradigm & Modernisation & Human development \\
\hline
\end{tabular}

- Inclusion: "development that provides opportunities and benefits for all, including those who have to a relative or absolute extent been excluded by development to date" (ibid.:26).

- Sustainability: "development that meets the needs of the present without compromising the ability of future generations to meet their own needs" (WCED, 1987:43).

If development has changed, then technology has changed even more. In order to build a framework for understanding this change, an inductive analysis was undertaken on literature linking ICTs to broad social trends. This produced the model shown in Figure 1; the first feature of which to note is another change in terminology-from "ICTs" to "digital"; reflecting not merely the pursuit of novelty but also the broader nature and role of these technologies than previously.

The inductive nature of the analysis means this is not the only way to understand this domain, so this cannot be claimed as a definitive basis for analysis. The framework is divided into three main parts. Foundations are underlying elements that create the basis for digital technology to relate to development. Building blocks are those components that relate to operationalisation of digital systems: operationalisation that has a direct link to the final part, which is the impact of those systems on development. There is no strict distinction between foundations and building blocks: these terms are used in part for analytical convenience.

Each of these first two will now be explored in more detail, in order to understand the changing nature of the relationship between digital and development. The issue of impacts on development will be dealt with in the companion Part 2 paper.

\section{DIGITAL FOUNDATIONS FOR DEVELOPMENT}

\subsection{Digital technologies}

\subsection{1 | General trends}

Key digital ICT trends in developing countries are summarised in Figure 2.

These figures smooth over many inequalities but the overall change is clear: in less than a decade-and-a-half, digital ICTs have moved from a peripheral to a core role in developing countries. This can be understood as three associated expansions along different dimensions of international development:

- Reach: in 2005-bar some subsidised incursions-digital technologies were largely the preserve of an urban elite in developing countries. This is no longer so, with a significant geographic and demographic expansion of ICTs such that they now reach most low-income communities, both urban and rural.

- Scope: in 2005, ICTs tended to cluster around a few focal development issues and applications. Now, ICTs are imbricated with all development issues and sectors.

- Depth: in 2005, ICTs tended to skate across the surface of development processes, adding a patina of email or perhaps a static website. Now, ICTs are increasingly part of all aspects of development processes: gathering data, supporting or making decisions, underpinning actions and communicating results. 


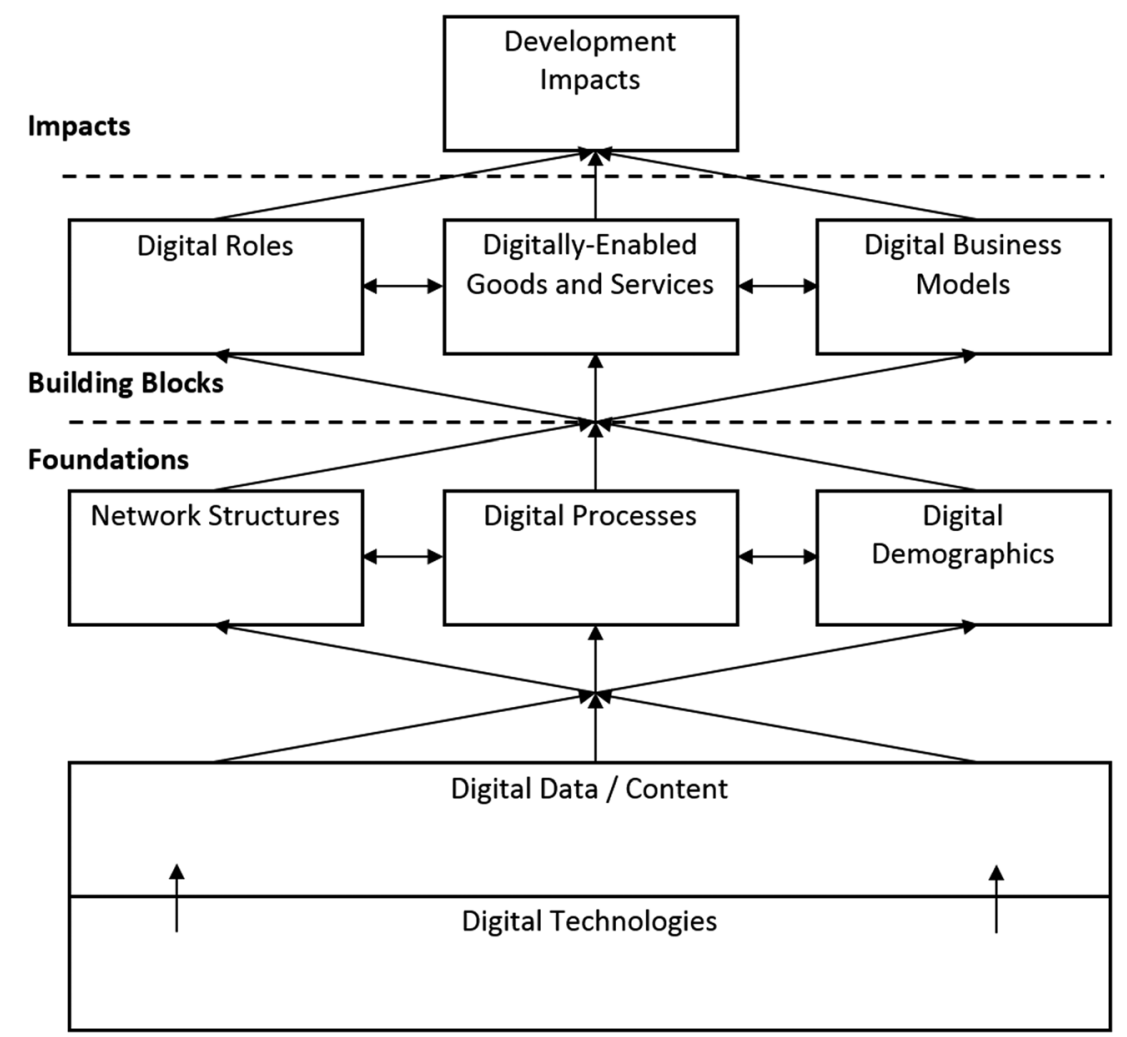

FIGURE 1 Framing the changing relationship between digital and development

We can thus talk seriously about the existence of a digital "nervous system" for development. This is a pervasive digital infrastructure in which most development organisations from international agencies through government departments to small community-based organisations have internet access-often broadband internet access-and in which most individuals in developing countries have digital mobile phone access.

ICTs are therefore moving from the exotic to the mundane in developing countries, from a specialist tool to an everyday utility with digital mediation emerging as the dominant mechanism for many processes of economic, political and cultural development. These changes both lay the ground and create the requirement for a new relationship between digital and development.

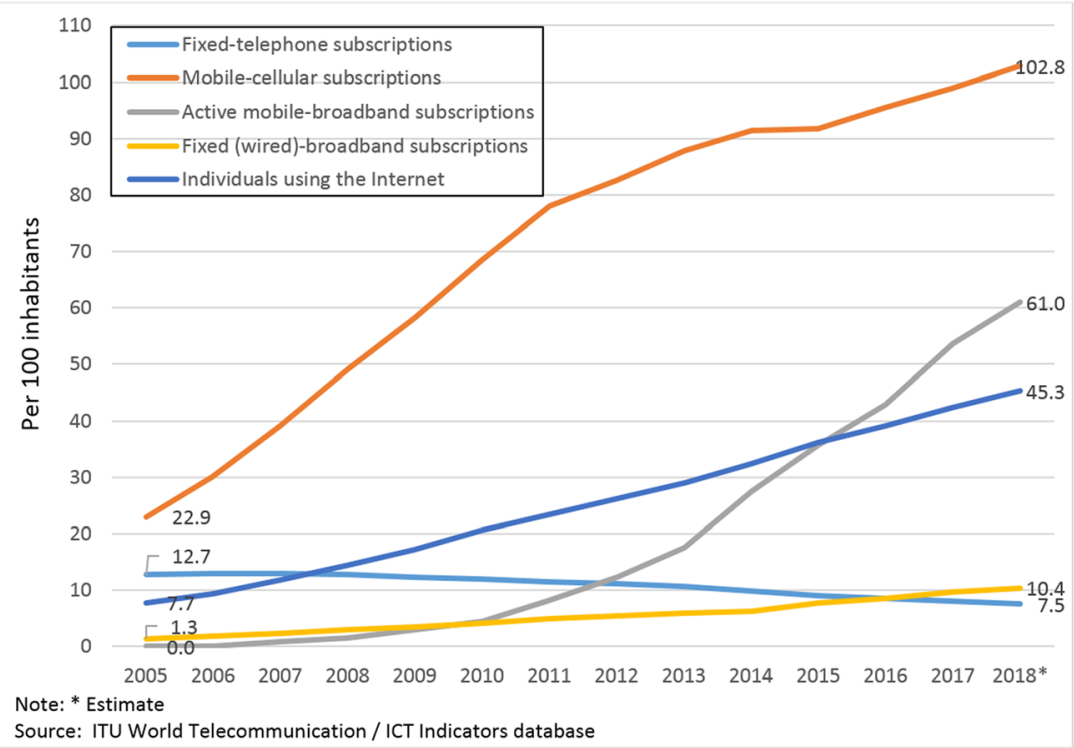

FIGURE 2 Key digital ICT indicators for developing countries (2005-2018) 


\subsection{2 | Specific technologies}

In a quote often attributed to Niels Bohr, "prediction is very difficult, especially about the future" (Ridgers, 2012:172). This certainly applies when seeking to understand which emerging ICTs will have a mainstream-as opposed to peripheral-impact on international development. As Figure 2 shows, we already have enough data to know that mobile, broadband and mobile broadband (hence smartphones ${ }^{2}$ and tablets) will be a key foundation. Social media likewise: in 2019 North America and Europe made up just 16\% of global social network users, with 60\% in Asia (including Oceania), $12 \%$ in Central/South America and 11\% in the Middle East and Africa (WAS, 2019) ${ }^{3}$ and with growth rates faster in the global South than the global North.

Cloud technologies-"a model of computing in which both data and applications are held in large data centres (or groups of data centres) which are remote from users' own terminal devices" (UNCSTD, 2013:16)-are already having a significant impact in developing countries. Most social media users, perhaps unwittingly, use cloud. Europe and North America were responsible for around 60\% of cloud traffic in 2018 , Asia Pacific for just under a third, while Latin America, the Middle East and Africa accounted for only 6\% (Cisco, 2018). However, by far, the highest growth rates are in the Middle East and Africa.

Similarly, digital platforms-"a set of digital resources-including services and content-that enable value-creating interactions between external producers and consumers" (Constantinides, Henfridsson, \& Parker, 2018:381)-are a major digital technology impacting development. Indeed, the "platformisation" of development can be understood as the key trend of the emerging digital-and-development relationship since it subsumes within it many of the other technologies discussed here. There are already hundreds of major platforms operating in developing countries, and many thousands of smaller ones (probably tens or hundreds of thousands given the definition above would encompass many apps). ${ }^{4}$ Trends of platformisation are seen across all sectors. To take just one example, digital labour platforms are estimated to provide employment in the global South for at least seven million "digital gig" workers (undertaking digital tasks on platforms like Upwork and Freelancer) and for tens of millions of "physical gig" workers (undertaking physical tasks such as taxi-driving or delivery on platforms like Uber and UberEats) (Heeks, 2019).

Of technologies likely to have a significant impact on development, the internet of things is a main contender: the internet connectivity of increasing numbers of objects. This has already happened in familiar ways with the increasing connectivity of mobile phones, tablets, laptops and PCs-10 billion devices were internet-connected in 2016 (ITU, 2016). But the main growth area-25 billion devices predicted by $2020-i s$ seen to be two types of connection: first, stand-alone sensors-for example providing agricultural readings from fields or medical readings from health centres (Deichmann, Goyal, \& Mishra, 2016; Islam, Kwak, Kabir, Hossain, \& Kwak, 2015), and second, sensors integrated into mainstream objects from cars and refrigerators to toilets and shoes (MIT Technology Review, 2014). All these applications become smart when they move from a passive ability to collect and transmit data to an active ability to take a decision and action on the basis of that data (Heeks, 2018) ${ }^{5}$ : smart irrigation systems that automatically water dry crops and smart electricity grids that automatically isolate and re-route around transmission failures.

Also likely to have an impact is an emerging set of telecommunications technologies that are helping to fill gaps in network coverage or speed. These derive from various technological directions but all have an aim of addressing digital inclusion. Examples include the following:

- Local-scale cellular networks, typically serving a few hundred or thousand users and using mesh or WiFi-based long distance networks (Johnson et al., 2016; Rey-Moreno, Miliza, Mweetwa, van Stam, \& Johnson, 2016).

- Local-scale wireless networking using the television white space spectrum: those frequencies within the TV broadcast range that are unused in a particular region (Chavez, Littman-Quinn, Ndlovu, \& Kovarik, 2016).

- Wider-scale networking via use of small or micro satellites, particularly of value in providing telecommunications coverage in the most-remote areas (Madry, Martinez, \& Laufer, 2018). As with TV white space, use of micro-satellites for low-income user access is still at an initial stage.

All of these are pushing the digital towards geographic universality.

There are fewer certainties as yet about more formative technologies that are only approaching the mainstream in the global North, let alone the global South. Examples about which there have been noteworthy aspirations for development include those sometimes associated with Industry 4.0 including 3D-printing, autonomous vehicles (including drones) and blockchain and robotics (Nagano, 2018; Schwab, 2016). Artificial intelligence/machine learning applications are also increasingly being applied to development issues (Mann \& Hilbert, 2018). These will all have an impact but are part of the medium-term future for digital-and-development rather than the immediate.

Digital ICTs have already moved us along the time dimension to a world of 24/7 everywhen connectivity (see Figure 3, adapted from ITU, 2005). Thanks to telecommunication advances, anywhere can now be connected, and we are slowly erasing the blank spaces on the digital map

\footnotetext{
${ }^{2}$ Population-weighted smartphone subscription penetration rates in developing countries in 2018 were equivalent to $42 \%$ of the population (though less than $20 \%$ in sub-Saharan Africa) (Newzoo, 2018).

${ }^{3}$ The US is the only global North country in the top eight Facebook-using countries by population (WAS, 2019).

${ }^{4}$ As an example, nearly 300 major platforms were identified operating across just eight countries in Africa (i2i, 2019).

${ }^{5}$ Though some usages of the term "smart" vary from this definition. Sensors/systems become "expert" or "intelligent" when they have the autonomous ability to learn; that is, to modify initiallyprogrammed patterns of decision and action on the basis of their past cycles of "behaviour".
} 


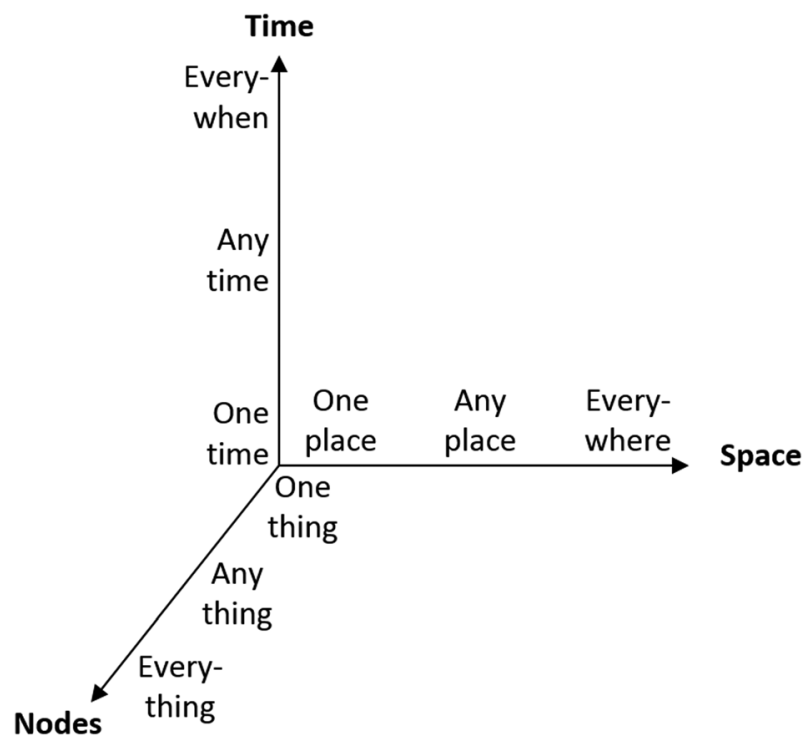

FIGURE 3 The growing domain of digital connectivity

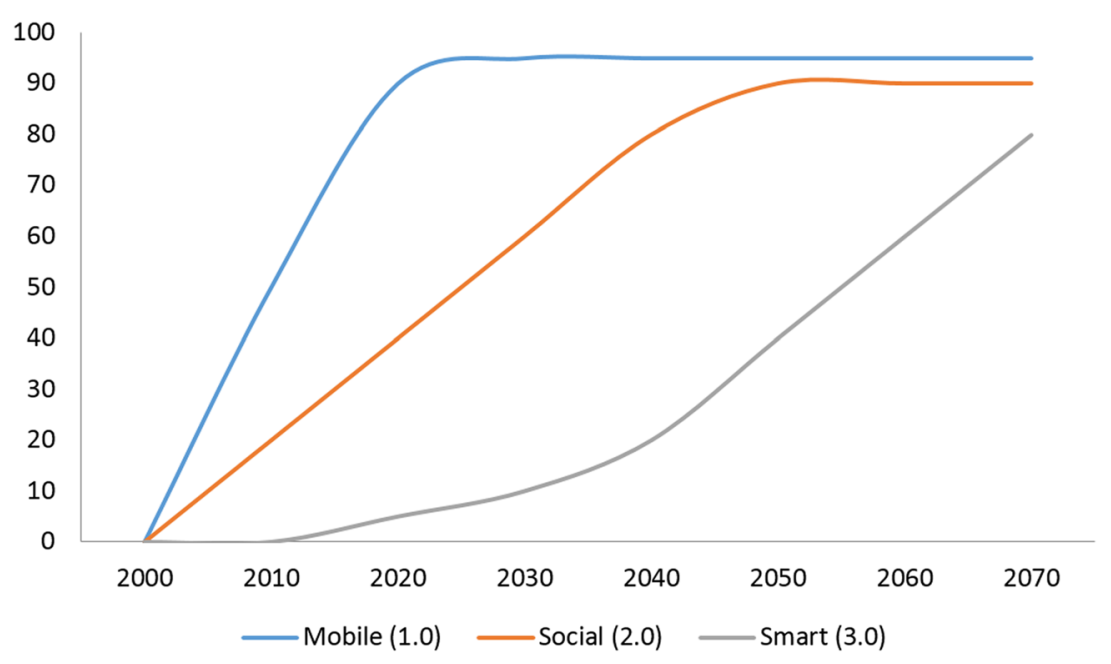

FIGURE 4 The generations of digital infrastructure for development

and moving towards everywhere being connected. In terms of nodes, pretty well anyone and anything could now be connected thanks to ubiquitous computing. There is a still a very long way to go but, within a generation, almost everyone will be connected, and we will be steadily moving closer to everything being connected (Greenfield, 2006), thus vastly multiplying the number of "points of potential control, resistance, and contestation" (Deibert \& Rohozinski, 2012:24).

We can therefore think of three generations of digital infrastructure for development (see Figure 4). The first, already well-rooted, is based largely around mobile phones. The second, fast-growing at the time of writing and increasingly overlapping with the first due to diffusion of smartphones, is based around the internet including Web 2.0 applications. The third, currently nascent, will be based around a ubiquitous computing model of sensors, embedded processing and near-universal connectivity and widespread use of smart applications.

\section{2 | Digital data/content/processes}

As a result of the spread of digital technology, a key trend in development is digitisation: conversion of data from analogue to digital. The development implications of digitisation can be approached from two directions: data-centric and process-centric.

For the first, digitisation has now progressed so far that we can talk of the "datafication" of development: widespread and growing presence, use and impact of digital data in development processes (Heeks \& Shekhar, 2019). The processes of decision and (trans)action will be fed by growth of the $5 \mathrm{Vs}$ of data that arise from digitisation (adapted from IBM, 2013): 
TAB LE 2 Regional share of global internet users $(2001,2018)$

\begin{tabular}{lll} 
Region & Percent (\%) share in 2001 & Percent (\%) share in 2018 \\
\hline Rising share & & 11 \\
Africa & 1 & 4 \\
Middle East & 1 & 10 \\
Latin America/Caribbean & 5 & 49 \\
Asia & 32 & 8 \\
Falling Share & & 1 \\
North America & 30 & 17 \\
Oceania & 2 & 29
\end{tabular}

- Volume: increasing amounts of data being produced. ${ }^{6}$

- Velocity: decreasing time between any process and the widespread availability of data about it.

- Variety: data from an increasing diversity of sources in an increasing variety of forms (including unstructured forms such as audio, video and conversations).

- Veracity: increasing objectivity of data as humans are disintermediated from the data capture and processing chain.

- Visibility: greater awareness and availability of data about processes.

The datafication of development is therefore not just a question of big data but also real-time data and open data (Heeks, 2018). These all-but particularly the volume trend-provide the foundation for the spread of artificial intelligence-based machine learning, as noted above.

A process-centric view would focus on digitalisation of development: the application of digitisation to organisational and social processes. Digitalised processes remain embedded in socio-technical contexts that constrain them, and there have been concerns that they become less, not more, flexible than their analogue counterparts; being set in "electronic concrete" (Heeks, 2006). In general, though, digitalisation of development processes has made them more flexible, enabling three abilities (Dunleavy, Margetts, Bastow, \& Tinkler, 2006; Sambamurthy, Bharadwaj, \& Grover, 2003):

- Process reengineering: the ability to redesign processes in order to maximise their efficiency.

- Process agility: the ability to redesign processes rapidly in response to environmental change.

- Process holism: the ability to redesign processes so that they integrate previously separate elements into a whole, larger process.

\section{3 | Digital demographics}

The technology changes outlined have had geographical, maturational and experiential impacts on the demographics of ICT usage.

Geographically, we have already moved from domination of the old internet world (the United States and Europe) to domination of the new internet world (emerging nations of the global East and South) (Bolsover, Dutton, Law, \& Dutta, 2014). The changing share of global internet users is summarised in Table 2 (IWS, 2019). ${ }^{7}$

The global shift from old to new internet world is both changing and perpetuating behaviour and values online. Compared with their old internet world counterparts, new internet world users are more sociable (in terms of willingness to connect with strangers online), produce more online content, are much more politically active, source more of their audio-visual content online and make use of a wider range of languages ${ }^{8}$ (Bolsover et al., 2014). They also spend more time online. As an example, in a global sample of 28 countries, all of the top 10 countries in terms of average number of daily hours of internet usage were developing countries; as were all of the top 10 in terms of average number of daily hours of social media use (WAS, 2019). However, there is a consistency of old and new world online attitudes towards issues like censorship and monitoring online, which "suggests that there is a distinctive set of global internet values, supporting privacy and freedom of expression that cuts across geographical, economic and social boundaries" (Bolsover et al., 2014:129).

\footnotetext{
"Every two days, more data is created than in the whole of human history up until 2003" (Piotrowski, 2014); "There are 2.5 quintillion bytes of data created each day at our current pace ... Over the last two years alone $90 \%$ of the data in the world was generated." (Marr, 2018).

${ }^{7}$ These aggregates hide various shifts, eg, Japan shrinking from $40 \%$ to $6 \%$ of Asian internet users and India growing from $4 \%$ to $22 \%$, and China from $20 \%$ to $39 \%$. China's online population surpassed that of the US in 2008 and there are more Chinese online than the entire population of Europe. Kenya and Uganda have as many internet users as the UK; the Middle East and Africa have more users than Western and Central Europe (IWS, 2019).

${ }^{8}$ There are far more Chinese-as-a-first-language than English-as-a-first language internet users as of 2019 (IWS, 2019) though Web content lags far behind-54\% of websites are identified as being in English, less than $2 \%$ as Chinese (W3Techs, 2019).
} 
Maturationally, there are individuals who are "growing up digital" (Tapscott, 1998) often referred to as "digital natives" with one definition stating they are 15-24 year olds with 5 or more years of online experience (ITU, 2013). ${ }^{9}$ The notion of digital natives is problematic for a number of reasons (ITU, 2013; Nash, 2014; Trucano, 2016): the danger of homogenising the experiences of young people, the majority of whom across the world are not digital natives; the danger of privileging age as a distinguishing feature worthy of attention above other divisions in societyincome, class, gender, geography, race, etc.; the danger of "othering" older people and older ICT users as somehow less important or less valuable; and the danger of slipping from the positive-evidence-based descriptions of digital natives, to the normative-assuming digital natives are a "good thing" that we need policy prescriptions to encourage.

The counter-rationale, for separate identification of these individuals, rests on two main arguments: first, that youth differ from older adults. For example, compared with the older adult population, young people are more likely to be unemployed, are less likely to vote, are more likely to subscribe to cultures that are alternative or resistant to dominant structures and less likely to trust mainstream political institutions; and perceive themselves to be more innovative and creative (Ansell, 2016; Farrugia, 2018; ILO, 2013; Nilan \& Feixa, 2006); and, second, that the way these individuals interact with digital technology is different from that of other groups. Perhaps not surprisingly, they are found to make greater use of digital technologies and social networks and to consume and produce more content online than users with fewer years of experience (Blank \& Dutton, 2014; Teo, 2016). There is also growing evidence that ICTs are changing the way we think and learn, with any impact being greater on digital natives: this being linked to arguments that engagement of digital natives (and others) via digital channels should be in addition to, rather than merely instead of, traditional channels (ITU, 2013; Lehrer, 2010; Marsh \& Rajaram, 2019).

Experientially, ICT users are experiencing changes that include the following (Avgerou, Hayes, \& La Rovere, 2016; Malecki, 2017; Molony, 2012; Ridley, 2009):

- Time-space compression: a shortening of timespans for activities, moving towards Castells' (2000) notion of "timeless time" in which biological and clock time are replaced by compressed, desequenced notions of time, and a new geography that replaces physical distance with virtual space so that individual experience moves from a "space of places" to a "space of flows" (ibid.).

- Public to private: moving from shared-use to individual-use models of ICT interaction. Voice communication is moving from public payphones to shared mobile phones to individually owned mobile/smartphones. Internet access is moving from public access telecentres and cybercafés to semi-public home or work computers to personal mobile devices. The digital experience thus becomes increasingly private and individualised.

- Fixed to mobile: as mobile devices become the dominant means of access to digital infrastructure and content. ${ }^{10}$

- Text/audio to audio-visual: while it may be premature to call the emergence of a post-literate society, increasing bandwidth and technical capabilities mean digital experiences can increasingly resemble rich, natural, real-life experiences rather than the artificial restrictions of just text or just audio.

One can argue that all four cases represent an increasing presence yet decreasing visibility of the digital as its mediation merges more seamlessly into everyday life and activities (Deuze, 2012; Thumim, 2017). This growth-but-disappearance of mediation thus represents a final experiential trend-that digital technologies more-and-more intercede between people and their experiences, and yet people notice them doing this less-andless. If the medium is the message, our conscious awareness of the message may be diminishing.

All three of these trends-geographical, maturational and experiential-form the emerging background underlying the changing nature of digital and development.

\subsection{Network structures}

Because the digital infrastructure is networked, there is a natural affinity between ICTs and real-world network structures; hence, the association with ideas such as "network society" (Castells, 2010) and the association with features of networks. However, some of these ideas appear to have been overstated:

- Chains: there has been an association of digital technologies in developing countries with disintermediation-the removal of one or more nodes in a chain of connections; for example, removal of "middlemen" between a buyer and seller (Jagun, Heeks, \& Whalley, 2008). But it is just as topographically feasible for ICTs to enable reintermediation-the insertion of new nodes in a chain of connections as, for example, happens with third-party suppliers working through platforms such as Amazon or eBay (Foster, Graham, \& Waema, 2019).

\footnotetext{
${ }^{9}$ Many different terms have been used to identify similar groups. A number send the message that this is a solid global cohort or generation: net generation (Tapscott, 2008), millennials (Howe \& Strauss, 2000), Generation C (connected, computerised, and content-producing) (Friedrich, Peterson, \& Koster, 2011). But these are inappropriate: even in the global North any individual age cohort grows up with radically varying digital experiences from total immersion to total exclusion (ITU, 2013), and the staggered diffusion of technology means global experiences differ (Thinyane, 2010). The selection of 15-24 years is also questionable given the greater experience of digital likely to be emerging in those under 15 years of age.

${ }^{10}$ For example, in $2005100 \%$ of global broadband subscriptions were fixed; by 2018 , only $17 \%$ were fixed and $83 \%$ were mobile (ITU, 2019).
} 
- Networks: the internet particularly is seen as a networked technology that is innately open with a flat structure and without central control (Naughton, 2010), and this has led to an association of the new relationship between digital and development with flat, peer-to-peer network structures-for example, social activists joining together in a social movement (eg, Thomas, 2019). But the exceptionalism of networks rests on the assumption that they are inherently different from the other two dominant forms of structure: markets and hierarchies. While that might be true of one particular form-the self-organised network ${ }^{11}$-markets and hierarchies are both networks in a more general sense of a set of interconnected nodes. ICTs have levelled a part of the playing field: hierarchies were traditionally better than self-organised networks at tasks such as coordination or focusing resources, and, with ICTs in place, this is no longer the case (Castells, 2000). However, ICTs enable every type of network and have thus been able to strengthen both markets and hierarchies as well (Heeks, 2018).

Therefore, in the general sense, networks will be the structural form of the future relation between digital and development. However, there is less technological determinism (and more social determinism) in this than might initially be expected from the discourse on networks. We are left with three other structural features of that future relation:

- Complexity: the network structures will involve more connections with more nodes (people, devices, organisations, etc.) and will thus be increasingly complex (Hanseth, 2007). Managing this complexity is beyond the capabilities of analogue systems and can only be done by digital systems which, in turn, add further connectivity and complexity. We thus have a positive feedback loop-"like the tightening of a knot" (Deibert, 1997:152)-that increases our dependency on digital technology. ${ }^{12}$

- Virtualisation: because of the digitalisation of processes, network structures will have less of a physical and more of a virtual existence (Mowshowitz, 1997). They therefore cut across the physical barriers of time and space, and they are more flexible-for example, easier to restructure by removing some nodes or adding others.

- Platformisation: as already noted, digital platforms will increasingly act as both central nodes in digital-and-development networks and as the infrastructures that house such networks (Koskinen, Bonina, \& Eaton, 2018). The ownership, governance, management, etc. of platforms will therefore increasingly shape the structure of the relationship between digital and development. Likewise, so will affordances of platforms such as network effects, user lock-in and dis-/re-intermediation.

\section{3 | DIGITAL BUILDING BLOCKS FOR DEVELOPMENT}

The technological foundations for the future of digital and development were outlined above, alongside some of the associated demographic changes, which are creating growing numbers in the global South for whom economic, political and social life is increasingly digitally-mediated and for whom ICTs are changing from a specific development tool to a general development platform.

Three of the trends outlined so far-digitisation/datafication, digitalisation, virtualisation-can be seen as inherent to the technology and thus to any new relationship to development that might be emerging. Three-the "Southernisation" and "nativisation" of users and the univeralisation of time, space and object connectivity-can be accepted as inherent to technology diffusion. The others ${ }^{13}$-individualisation, mobilisation and "real"isation of digital experience; and complexification, flexibilisation and platformisation-are so universal as to be effectively inherent to any future digital-development relationship though they all reflect design or implementation decisions with human input.

But we can now turn to the further implications of these foundational trends; specifically their impact on the three building blocks of the digital-development relationship: roles, products and business models. These elements move further away from the technology and increasingly reflect human intervention and choice. Put another way, they shift along the continuum from technology shaping society to society shaping the way technology is implemented and used.

\subsection{Digital roles}

As citizens in developing countries interact with digital technology, they take on a range of different roles, which can be understood as a "role ladder" (see Figure 5; Heeks, 2014b; Heeks, 2018). In simple terms, climbing the ladder can be read as a greater intensity of engagement with digital technology, moving from no direct use to direct use to use sufficient to be classified as falling within the digital economy. It is also a ladder of

\footnotetext{
11"We define a [self-organised] network form of organization as any collection of actors $(N \geq 2)$ that pursue repeated, enduring exchange relations with one another and, at the same time, lack a legitimate organizational authority to arbitrate and resolve disputes that may arise during the exchange" (Podolny \& Page, 1998:59).

${ }^{12} \mathrm{~A}$ further example of this relates to time since ICTs "both manage and exacerbate time intensification" (Henman, 2010:208); helping us to control ever-accelerating schedules while

simultaneously accelerating those schedules yet further.

${ }^{13}$ Lexicographers, please look away now.
} 
Digital Role

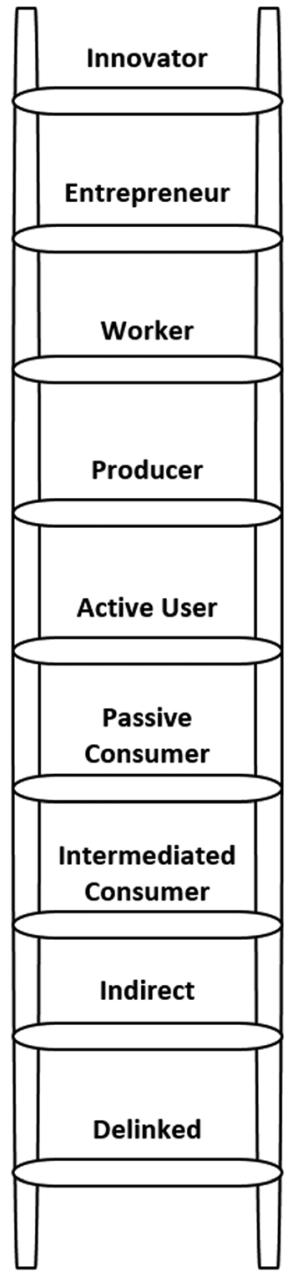

Digital Category

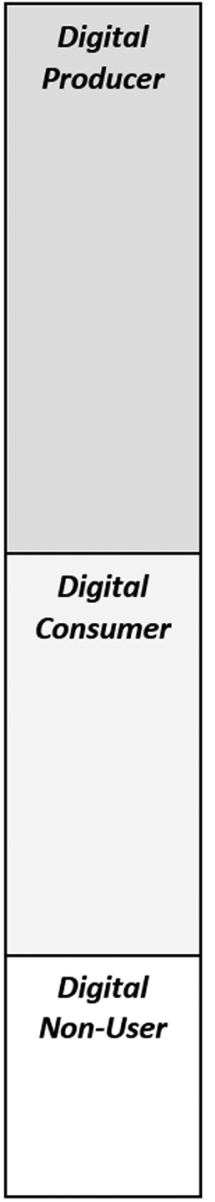

FIGURE 5 Ladder of digital roles

technological capability, each step reflecting higher-level competencies (skills, knowledge and attitudes) that are required for this type of ICT use but that are also created by this type of ICT use.

Digital technologies have accelerated a conflation of roles, in particular, "prosumption"-the conflation of roles of consumer and producer (Ritzer \& Jurgenson, 2010). Examples include the following:

- Passive prosumption: everything users do online produces a trail-their "digital shadow" or "digital exhaust" or "digital footprint"-that creates value, which is increasingly captured and monetised.

- Semi-active prosumption: e-business and e-government users take on a small production role in consuming services; for example, in entering various details about themselves or the particular product or service they want.

- Active prosumption: users of social networking platforms are responsible for producing much of the content of those platforms-what would Facebook or Weibo look like without their users?

In the great majority of cases, this free labour is given willingly or at least unwittingly, but it helps power important parts of the digital economy. ${ }^{14}$

\footnotetext{
${ }^{14}$ Estimates of its value vary because they are difficult to define. Facebook's estimate of just under US $\$ 5$ per "prosumer" per year could be used. This would translate into around 7.5 US cents per hour average unpaid "wage" given the average user spends 65 hours per year on Facebook (Fuchs, 2014; Gross, 2012) (tiny per-user figures but with more than 2.4 billion users it explains how the company earns c.US $\$ 56$ billion in revenue with little more than 30,000 employees (WP, 2019)). An alternative valuation-admittedly by privacy protection firm reputation.com-puts the value of personal data released online at between US $\$ 50$ and US $\$ 5,000$ per person per year (Fottrell, 2012).
} 
TABLE 3 Digital business models

\begin{tabular}{|c|c|c|}
\hline Main category & Sub-category & Example \\
\hline \multirow{3}{*}{$\begin{array}{l}\text { Content: collection, selection, compilation, distribution } \\
\text { and/or presentation of online content }\end{array}$} & Content provider: organisation provides digital content & iTunes \\
\hline & $\begin{array}{l}\text { Community provider: provides framework for communication of digital } \\
\text { content between users with common interests }\end{array}$ & Facebook \\
\hline & $\begin{array}{l}\text { Service provider: organisation adds value to user-provided digital } \\
\text { content }\end{array}$ & Dropbox \\
\hline $\begin{array}{l}\text { Commerce: initiation, negotiation and/or fulfilment of } \\
\text { online transactions }\end{array}$ & Market creator: enables buyers and sellers to transact & eBay \\
\hline Context: aggregation and sorting of online content & Portal: adds value to existing digital content & Google \\
\hline $\begin{array}{l}\text { Connection: provision of physical or virtual network } \\
\text { infrastructure }\end{array}$ & Internet service provider: provides access to digital infrastructure & China Telecom \\
\hline
\end{tabular}

\section{2 | Digitally-enabled goods and services}

There are attempts to measure the size of the ICT sector ${ }^{15}$ or the digital economy ${ }^{16}$ (eg, BCG, 2012; Bukht \& Heeks, 2017; EC, 2014; McKinsey, 2011; OECD, 2013). These sources suggest that-even together and allowing for overlaps-these represent less than 10\% of GDP, even in the more developed economies of the world. A best overall estimate is that the digital economy makes up "around 5\% of global GDP and $3 \%$ of global employment" (ibid.:1), with developing countries likely to be around one-third to one-half this level. These sectors are growing faster than the general economy, particularly in the global South, but the majority of ICT gains are captured by the "traditional" economy. Measuring the total digitalised economy-ie, all value addition from digital activity-has always been a near-impossible task due to problems of definition, measurement and availability of data; and EC (2014:6) flatly concludes, "Given that digital business models are present in more and more sectors of the economy it is not possible to come up with the size of the [digitalised] economy as a percentage of GDP". ${ }^{17}$

What one can conclude is that there are two trends around digital outputs-goods and services (Coyle, 1997):

a. A smaller trend for the creation of new digital products that did not previously exist ("amaterialisation"). An obvious example would be software, with ever-growing production of software within developing countries (Nguyen, Umemoto, \& Dam, 2014; Kamel, 2019).

b. A larger trend for the digitisation of existing products, causing their "dematerialisation;" that is, their conversion from a physical to a virtual product. This is occurring in almost all sectors and examples include the conversion of books into e-books, conversion of newspapers into news websites and conversion of classroom education into e-learning. Mobile payment systems like M-Pesa not only dematerialise money but also create a platform that enables dematerialisation of a whole range of other financial services such as banking, savings and insurance (Kim, Zoo, Lee, \& Kang, 2018).

Because new and existing products and/or the processes used to create them are increasingly digital and thus flexible, another trend is enabled: customisation (Wind \& Rangaswamy, 2001; Wirtz, Schilke, \& Ullrich, 2010). This is the increasing ability of goods and services to be differentiated to meet the needs or wants of particular consumers. Combined with emergence of the "bottom-of-the-pyramid" as a market, this is seeing growth in digital products customised for the poor in developing countries (Arora, 2019; Seetharaman, Cunha, \& Effah, 2019).

\subsection{Digital business models}

As just noted, the major uses of digital ICTs are still in traditional organisations. As a result, most digital business models are just business models-traditional ways of doing things but with the overlayering of ICTs. What will be new in the future relationship of digital to development, though, will be truly digital business models. Drawing from the private sector but applicable also in public and NGO sectors in development, these are summarised in Table 3 (adapted from Wirtz et al., 2010; Laudon \& Laudon, 2018), with most representing different types of digital platform.

\footnotetext{
${ }^{15}$ Covering telecommunication services, web/cloud-based services, device manufacturers, component manufacturers, and software (EC, 2012).

${ }^{16}$ Covering "that part of economic output derived solely or primarily from digital technologies with a business model based on digital goods or services" (Bukht \& Heeks, 2017:1)

${ }^{17}$ The same is likely to be true of the "internet economy", covering "the full range of our economic, social and cultural activities supported by the internet and related information and communications technologies" (OECD, 2008:4).
} 


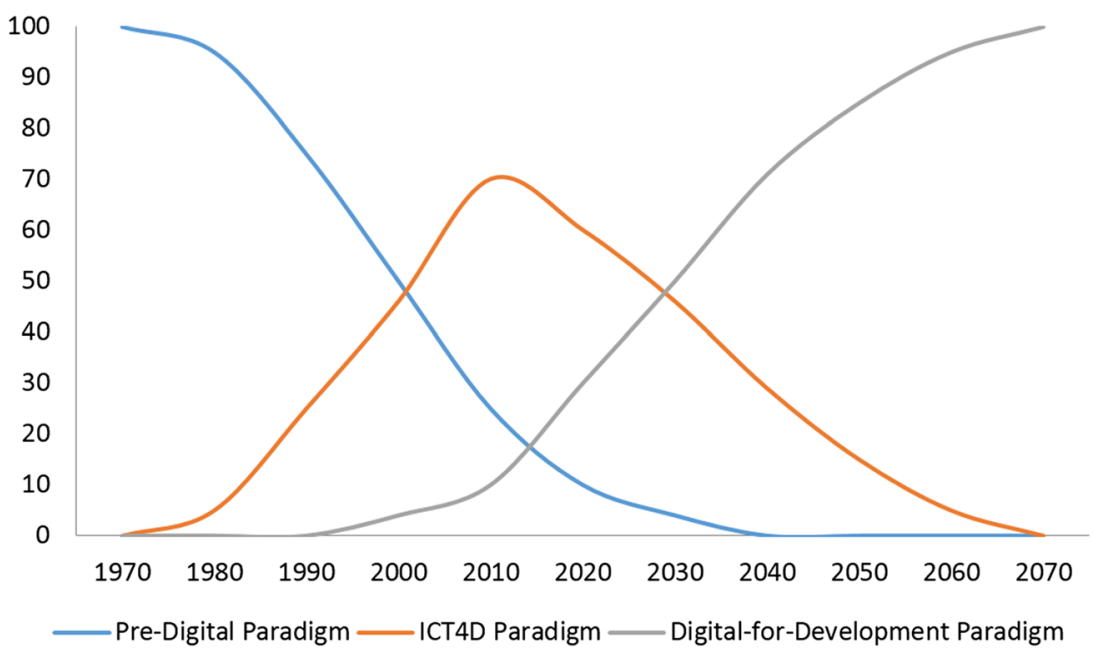

FIGURE 6 Changing paradigms of ICTs and development

However, Table 3's categorisation does not expose some of the key novelties around digital business models, particularly for organisations that are not commercial businesses. These can be better summed up as four features that some business models reflect (Benkler, 2004; Chesborough, 2006; Libert, Beck, \& Wind, 2016; Mowshowitz, 1997; Walter \& Back, 2010):

- Virtual: the untying of business models from physical restrictions, therefore enabling value chain activities (sourcing inputs, processing inputs into outputs, distributing outputs, managing the value chain, etc.) to locate anywhere (that has a digital connection).

- Open: the breaking of traditional boundaries and opacity of value chain activities to enable much greater transparency and involvement of a wider range of external stakeholders including models of co-sourcing, co-production, co-distribution and co-consumption.

- Crowd: the opening of value chain activities to a large group of not-pre-identified individuals, which may include sourcing inputs (eg, crowdfunding), processing inputs into outputs (eg, crowdsourcing completion of digital tasks) and distributing outputs (eg, crowdsharing).

- Shared: the sharing of the value of any resource beyond a single individual (eg, owner) relating to any value chain activity though typically related to final consumption of the resource.

Both the models and novelties will increasingly be seen in the operation of organisations working in developing countries.

\section{4 | CONCLUSIONS}

This paper has mapped out elements of the changing relationship between ICTs and development, now increasingly referred to as the relationship between digital and development. The focus was not particularly top-down; in other words, little was said about the changing development context: the greater focus on transformation, inclusion and sustainability arising from the advent of the Sustainable Development Goals. And nothing was said about the universalisation of the notion of development. Those issues must be left for another day.

Instead, a more bottom-up picture was built. Mobile, broadband, smartphones, social media, cloud and platforms are already integral to digital and development. They have created this "digital nervous system" for development that is spreading fast in terms of reach, scope and depth, spurred further by the new telecommunication technologies that fill in the relatively few remaining blank spaces on the digital map and by the growth of the internet of things. The technologies of Industry 4.0 play a more formative role as yet but are likely to have a substantial impact in the coming decade.

That technological base is digitising development, leading to a datafication and digitalisation of development processes. This is already having widespread implications for development efficiency and effectiveness but also for issues of social justice, inequality and more. The base is also digitalising the demographics of development: shifting the online world's centre of power East and South, creating digital natives who may differ in some ways from past user groups, pushing users up the ladder of digital engagement and capabilities, and changing how users experience the world even as the technology itself fades into the quotidian background of individual lives. Complex, virtualised, platform-based networks are increasingly the structural basis for development, delivering goods and services that are increasingly dematerialised and customisable via a set of new business models that can disrupt traditional development through their efficiency, virtuality, openness, etc. 
Looking back at the summary descriptors for ICT4D 2.0, some issues remain the same: the potential view of the poor, and models of innovation. But other elements have changed: the iconic technology is now the digital platform, the key goals are the SDGs, and the key issue is now impact alone. And there are new issues of importance: the universality of the technology, concerns about both development downsides as well as benefits, and the different nature of user engagement with the technology.

We can, therefore, at least start to talk of a new paradigm, a new worldview in the relation between the technology and development. We could call this "ICT4D 3.0," and there would be good reasons for that, indicating the continuity with past ideas and reinforcing the identity value of the "ICT4D" label. But it could also be a good moment to change terminology to "digital," calling this either a "digital development" paradigm or, with a clearer sense of purpose and less opportunity for confusion with other meanings, a "digital-for-development" paradigm. ${ }^{18}$

\section{1 | An emerging "digital-for-development" paradigm}

Following that logic, the longer-term relationship between digital information and communication technologies and international development could be divided into three paradigms-"pre-digital," "ICT4D" and "digital-for-development"-that rise and fall over time (see Figure 6).

The pre-digital paradigm dominated from the mid-1940s to mid-1990s and conceptualised a separation between digital ICTs and development (Heeks, 2009). During this period, digital ICTs were increasingly available, but they were initially ignored by the development mainstream. When, later, digital technologies began to diffuse into developing countries, they were still isolated from the development mainstream. ICTs were used to support the internal processes of large public and private organisations or to create elite IT sector jobs in a few countries. But they did not touch the lives of the great majority of those living in the global South.

The ICT4D paradigm has emerged since the mid-1990s, first as ICT4D 1.0 as discussed in Section 1 and then as ICT4D 2.0. It has conceptualised digital ICTs as a useful tool for development (ibid.). The paradigm arose because of the rough synchrony between general availability of the interneta tool in search of purposes, and the Millennium Development Goals-a purpose in search of tools. ICTs were initially idolised as the tool for delivery of development but later began to be integrated more into development plans and projects as a tool for delivery of development.

The isolationism of the pre-digital paradigm remains present: we still find policy content and policy structures that segregate ICTs. But integrationism is progressing, mainstreaming ICTs as a tool to achieve the various development goals. From the development side, we see this expressed in national policy portfolios, in Poverty Reduction Strategy Papers and in UN Development Assistance Frameworks. From the ICT side, we see this expressed in national ICT policies and World Summit on the Information Society action lines.

Yet, just at the moment when this paradigm in its ICT4D 2.0 form is starting to be widely adopted within national and international development systems, a new form is hoving into view. This is the digital-for-development paradigm with the components as just described. If one wanted to summarise the key difference to the ICT4D paradigm, one could say that it conceptualises ICT not as one tool among many that enables particular aspects of development but as the platform that increasingly mediates development.

It is still early days in understanding the current inflection point in the relationship between digital ICTs and international development. Hopefully, this paper can act as a launch pad for further work, tracing the detail of any new paradigm as shown in Figure 6 but also looking for "big picture" aspects of the paradigm. This latter task is the focus for the associated Part 2 paper, which examines the impact of the digital-fordevelopment paradigm on the balance between two organising logics of economics and politics in developing countries: a logic of competition and a logic of cooperation.

\section{ACKNOWLEDGEMENTS}

This paper includes revised and updated text that earlier appeared in: Heeks, R. (2016) Examining "Digital Development": The Shape of Things to Come?, GDI Development Informatics Working Paper no.64, University of Manchester, UK. Development of that earlier paper was stimulated and supported by the UN Commission on Science and Technology for Development Secretariat, located within the UN Conference on Trade and Development.

\section{ORCID}

Richard Heeks (D) https://orcid.org/0000-0002-4551-2208

\section{REFERENCES}

Ansell, N. (2016). Children. Routledge, Abingdon, UK: Youth and Development.

Arora, P. (2019). The next billion users: Digital life beyond the West. Cambridge, MA: Harvard University Press.

Avgerou, C., Hayes, N., \& La Rovere, R. L. (2016). Growth in ICT uptake in developing countries: New users, new uses, new challenges. Journal of Information Technology, 31, 329-333.

\footnotetext{
${ }^{18}$ In August 2019, I created a Facebook poll asking those involved in the field whether "digital development" or "digital-for-development" was the more appropriate terminology. The vote was 79 to 5 in favour of the latter. For more thoughts on this, and support for "digital development" as the preferred term, see Roberts (2019).
} 
BCG (2012). The Internet economy in the G-20. Boston, MA: Boston Consulting Group. https://www.bcg.com/documents/file100409.pdf

Benkler, Y. (2004). Sharing nicely: on shareable goods and the emergence of sharing as a modality of economic production. Yale Law Journal, 114, 273-358.

Blank, G., \& Dutton, W. H. (2014). Next generation Internet users: A new digital divide. In M. Graham, \& W. H. Dutton (Eds.), Society and the Internet (pp. 36-52). Oxford, UK: Oxford University Press.

Bolsover, G., Dutton, W. H., Law, G., \& Dutta, A. (2014). China and the US in the new Internet world. In M. Graham, \& W. H. Dutton (Eds.), Society and the Internet (pp. 117-134). Oxford, UK: Oxford University Press.

Bukht, R., \& Heeks, R. (2017). Defining, conceptualising and measuring the digital economy. UK: GDI Development Informatics Working Paper no.68, University of Manchester. https://diode.network/publications/

Castells, M. (2000). Materials for an exploratory theory of the network society. British Journal of Sociology, 51(1), 5-24.

Castells, M. (2010). The information age: Economy, society, and culture (2nd ed.). Chichester, UK: Wiley-Blackwell.

Chavez, A., Littman-Quinn, R., Ndlovu, K., \& Kovarik, C. L. (2016). Using TV white space spectrum to practise telemedicine. Journal of Telemedicine and Telecare, 22(4), 260-263.

Chesborough, H. (2006). Open business models. Boston, MA: Harvard Business School Press.

Cisco (2018). Cisco Global Cloud Index. San Jose, CA: Cisco.

Constantinides, P., Henfridsson, O., \& Parker, G. G. (2018). Introduction-Platforms and infrastructures in the digital age. Information Systems Research, 29(2), 381-400.

Coyle, D. (1997). The weightless world. Oxford, UK: Capstone.

Deibert, R. (1997). Parchment, Printing and Hypermedia. New York, NY: Columbia University Press.

Deibert, R., \& Rohozinski, R. (2012). Contesting cyberspace and the coming crisis of authority. In R. J. Deibert, J. G. Palfrey, R. Rohozinski, \& J. Zittrain (Eds.), Access contested: Security, identity, and resistance in Asian cyberspace (pp. 21-41). Cambridge, MA: MIT Press.

Deichmann, U., Goyal, A., \& Mishra, D. (2016). Will digital technologies transform agriculture in developing countries? Washington, DC: World Bank.

Deuze, M. (2012). Media life. Cambridge, UK: Polity Press.

Dunleavy, P., Margetts, H., Bastow, S., \& Tinkler, J. (2006). Digital era governance: IT corporations, the State, and e-government. Oxford, UK: Oxford University Press.

EC (2012). Information and Communications Technology (ICT) Sector. Brussels: EU Skills Panorama, European Commission. http://euskillspanorama.cedefop. europa.eu/docs/AnalyticalHighlights/ICTSector_en.pdf

EC (2014). Digital economy-Facts \& figures. Brussels: Expert Group on Taxation of the Digital Economy, European Commission. http://ec.europa.eu/ taxation_customs/resources/documents/taxation/gen_info/good_governance_matters/digital/2014-03-13_fact_figures.pdf

Farrugia, D. (2018). Spaces of youth: Work, citizenship and culture in a global context. Abingdon, UK: Routledge.

Foster, C., Graham, M., \& Waema, T. M. (2019). Making sense of digital disintermediation and development: The case of the Mombasa tea auction. In M. Graham (Ed.), Digital economies at global margins (pp. 55-78). Cambridge, MA: MIT Press.

Fottrell, Q. (2012). Who would pay $\$ 5,000$ to use Google? (You), MarketWatch, 25 Jan http://blogs.marketwatch.com/realtimeadvice/2012/01/25/whowould-pay-5000-to-use-google-you/?mg=blogs-sm

Friedrich, R., Peterson, M., \& Koster, A. (2011). The rise of Generation C. strategy+business, 62, 1-8. http://www.strategy-business.com/media/file/sb62 11110.pdf

Fuchs, C. (2014). Digital prosumption labour on social media in the context of the capitalist regime of time. Time \& Society, 23(1), 97-123.

Greenfield, A. (2006). Everyware: The dawning age of ubiquitous computing. Berkeley, CA: New Riders.

Gross, D. (2012). How you help Facebook make billions, CNN Tech, 16 May http://edition.cnn.com/2012/05/16/tech/social-media/facebook-users-ads/

Hanseth, O. (2007). Integration-complexity-risk: The making of information systems out-of-control. In O. Hanseth, \& C. Ciborra (Eds.), Risk, complexity and ICT (pp. 1-20). Cheltenham, UK: Edward Elgar.

Heeks, R. (2006). Implementing and managing eGovernment. London: Sage.

Heeks, R. (2009). The ICT4D 2.0 Manifesto: Where next for ICTs and international development?, Development Informatics Working Paper no.42. UK: IDPM, University of Manchester. https://www.gdi.manchester.ac.uk/research/publications/di/di-wp42/

Heeks, R. (2014a). From the MDGs to the Post-2015 Agenda, Development Informatics Working Paper no.56. UK: IDPM, University of Manchester. https:// www.gdi.manchester.ac.uk/research/publications/di/di-wp56/

Heeks, R. (2014b). ICTs and Poverty Eradication, Development Informatics Working Paper no.58. UK: IDPM, University of Manchester. https://www.gdi. manchester.ac.uk/research/publications/di/di-wp58/

Heeks, R. (2014c). ICT4D 2016, Development Informatics Working Paper no.59. UK: IDPM, University of Manchester. https://www.gdi.manchester.ac.uk/ research/publications/di/di-wp59/

Heeks, R. (2018). Information and communication technology for development. Abingdon, UK: Routledge.

Heeks, R. (2019). How many platform workers are there in the global South?, ICT4DBlog, 29 Jan https://ict4dblog.wordpress.com/2019/01/29/howmany-platform-workers-are-there-in-the-global-south/

Heeks, R., \& Shekhar, S. (2019). Datafication, development and marginalised urban communities: An applied data justice framework, Information. Communication \& Society, 22(7), 992-1011.

Henman, P. (2010). Governing electronically: E-Government and the reconfiguration of public administration, Policy and Power. Basingstoke, UK: Palgrave Macmillan.

Horner, R., \& Hulme, D. (2019). From international to global development: New geographies of 21st century development. Development and Change, 50(2), 347-378.

Howe, N., \& Strauss, W. (2000). Millennials rising. New York, NY: Vintage Books.

i2i (2019). African digital platforms database. Midrand, South Africa: Insight2Impact. http://access.i2ifacility.org/Digital_platforms/

IBM (2013). The four V's of big data. NY: IBM, Armonk. http://www.ibmbigdatahub.com/infographic/four-vs-big-data

ILO (2013). Global employment trends for youth 2013. Geneva: International Labour Organisation.

Islam, S. R., Kwak, D., Kabir, M. H., Hossain, M., \& Kwak, K. S. (2015). The internet of things for health care: A comprehensive survey. IEEE Access, 3 , 678-708. 
ITU (2005). The internet of things. Geneva: International Telecommunication Union. http://www.itu.int/wsis/tunis/newsroom/stats/The-Internet-ofThings-2005.pdf

ITU (2013). Measuring the information society 2013. Geneva: International Telecommunication Union. http://www.itu.int/en/ITU-D/Statistics/Pages/ publications/mis2013.aspx

ITU (2016). Harnessing the internet of things for global development. Geneva: International Telecommunication Union.

ITU (2019). World telecommunication/ICT indicators database 2018. Geneva: International Telecommunication Union.

IWS (2019). Internet usage statistics, Internet World Stats http://www.internetworldstats.com/stats.htm

Jagun, A., Heeks, R., \& Whalley, J. (2008). The impact of mobile telephony on developing country micro-enterprise: A Nigerian case study. Information Technologies \& International Development, 4(4), 47-65.

Johnson, D., Zlobinsky, N., Lysko, A., Lamola, M., Hadzic, S., Maliwatu, R., \& Densmore, M. (2016). Head to head battle of TV white space and WiFi for connecting developing regions. In M. Gervais, O. Samuel, I. Dioum, \& O. Thiare (Eds.), International Conference on e-Infrastructure and e-Services for Developing Countries (pp. 186-195). Springer, Cham.

Kamel, S. H. (2019). The potential role of the software industry in supporting economic development. In M. Khosrow-pour (Ed.), Advanced methodologies and technologies in government and society (pp. 444-455). Hershey, PA: IGI Global.

Kim, M., Zoo, H., Lee, H., \& Kang, J. (2018). Mobile financial services, financial inclusion, and development: A systematic review of academic literature. The Electronic Journal of Information Systems in Developing Countries, 84(5), e12044.

Koskinen, K., Bonina, C., \& Eaton, B. (2018). Digital platforms in the global South: Foundations and research agenda, DIODE paper no.8. UK: Centre for Development Informatics, University of Manchester.

Laudon, K. C., \& Laudon, J. P. (2018). Management information systems (15th ed.). Harlow, UK: Pearson Education.

Lehrer, J. (2010). Our cluttered minds, The New York Times, 3 Jun http://www.nytimes.com/2010/06/06/books/review/Lehrer-t.html

Libert, B., Beck, M., \& Wind, J. (2016). The network imperative: How to survive and grow in the age of digital business models. Cambridge, MA: Harvard Business Review Press.

Madry, S., Martinez, P., \& Laufer, R. (2018). Innovative design, manufacturing and testing of small satellites. Springer, Cham.

Malecki, E. J. (2017). Real people, virtual places, and the spaces in between. Socio-Economic Planning Sciences, 58, 3-12.

Mann, S. \& Hilbert, M. (2018). Al4D: Artificial intelligence for development, SSRN https://ssrn.com/abstract=3197383

Marr, B. (2018). How much data do we create every day?, Forbes, 21 May https://www.forbes.com/sites/bernardmarr/2018/05/21/how-much-data-dowe-create-every-day-the-mind-blowing-stats-everyone-should-read

Marsh, E. J., \& Rajaram, S. (2019). The digital expansion of the mind: implications of internet usage for memory and cognition. Journal of Applied Research in Memory and Cognition, 8(1), 1-14.

McKinsey (2011). Internet matters: The net's sweeping impact on growth, jobs, and prosperity. New York, NY: McKinsey Global Institute. http://www. mckinsey.com/features/sizing_the_internet_economy

MIT Technology Review (2014). The Internet of things, MIT Technology Review, Business Report, July/Aug, 1-14

Molony, T. (2012). ICT and human mobility: Cases from developing countries and beyond. Information Technology for Development, 18(2), 87-90.

Mowshowitz, A. (1997). Virtual organization. Communications of the ACM, 40(9), 30-37.

Nagano, A. (2018). Economic growth and automation risks in developing countries due to the transition toward digital modernity. In A. Kankanhalli, A. Ojo, \& D. Soares (Eds.), Proceedings of the 11th International Conference on Theory and Practice of Electronic Governance (pp. 42-50). New York, NY: ACM.

Nash, V. (2014). The politics of children's Internet use. In M. Graham, \& W. H. Dutton (Eds.), Society and the Internet (pp. 67-80). Oxford, UK: Oxford University Press.

Naughton, J. (2010). Everything you ever need to know about the internet, The Observer, 20 Jun, 8-11 http://www.theguardian.com/technology/2010/ jun/20/internet-everything-need-to-know

Newzoo (2018). Global Mobile Market Report 2018. Amsterdam: Newzoo.

Nguyen, T. H., Umemoto, K., \& Dam, H. C. (2014). The knowledge-bridging process in software offshoring from Japan to Vietnam. The Electronic Journal of Information Systems in Developing Countries, 64(1), 1-29.

Nilan, P., \& Feixa, C. (Eds.) (2006). Global youth? Hybrid identities, plural worlds. London: Routledge.

OECD (2008). The Seoul Declaration for the future of the internet economy. Paris: OECD. http://www.oecd.org/internet/consumerpolicy/40839436.pdf

OECD (2013). Measuring the internet economy. Paris: OECD. https://doi.org/10.1787/5k43gjg6r8jf-en

Piotrowski, J. (2014). Big obstacles ahead for big data for development, SciDev. Net, 15 Apr http://www.scidev.net/global/data/feature/obstacles-bigdata-development.html

Podolny, J. M., \& Page, K. L. (1998). Network forms of organization. Annual Review of Sociology, 24, 57-76.

Rey-Moreno, C., Miliza, J., Mweetwa, F., van Stam, G., \& Johnson, D. (2016). Community networks in the African context: Opportunities and barriers. In K. Awori, \& N. J. Bidwell (Eds.), Proceedings of the First African Conference on Human Computer Interaction (pp. 237-241). New York, NY: ACM.

Ridgers, B. (Ed.) (2012). Book of business quotations. London: The Economist.

Ridley, M. (2009). Beyond literacy. In D. M. Mueller (Ed.), Pushing the edge (pp. 210-213). Chicago, IL: American Library Association.

Ritzer, G., \& Jurgenson, N. (2010). Production, consumption, prosumption: The nature of capitalism in the age of the digital 'prosumer'. Journal of Consumer Culture, 10(1), 13-36.

Roberts, T. (2019) Digital development: What's in a name?, Appropriating Technology, 9 Aug http://appropriatingtechnology.org/?q=node/302

Sambamurthy, V., Bharadwaj, A., \& Grover, V. (2003). Shaping agility through digital options. MIS Quarterly, 27(3), 237-263.

Schwab, K. (2016). The Fourth Industrial Revolution. Geneva: World Economic Forum.

Seetharaman, P., Cunha, M. A., \& Effah, J. (2019). IT for the informal sector in developing countries: A broader perspective. The Electronic Journal of Information Systems in Developing Countries, 85(3), e12093.

Tapscott, D. (1998). Growing up digital. New York, NY: McGraw-Hill.

Tapscott, D. (2008). Grown up digital. New York, NY: McGraw-Hill.

Teo, T. (2016). Do digital natives differ by computer self-efficacy and experience? An empirical study. Interactive Learning Environments, 24(7), 1725-1739.

Thinyane, H. (2010). Are digital natives a world-wide phenomenon. Computers \& Education, 55(1), 406-414. 
Thomas, P. N. (2019). Communicating for social change: Context, social movements and the digital. New Delhi: Sage Publications.

Thumim, N. (2017). Personal media. In P. Rossler (Ed.), The International Encyclopedia of Media Effects (pp. 1-13). Chichester, UK: John Wiley.

UNCSTD (2013). Issues paper on ICTs for inclusive social and economic development. Geneva: UN Commission on Science Technology and Development. http://unctad.org/meetings/en/SessionalDocuments/CSTD2013_Issues01_ICT.pdf

W3Techs (2019). Usage of content languages for websites. Austria: Q-Success, Maria Enzersdorf. http://w3techs.com/technologies/overview/content_ language/all

Walter, T.P. \& Back, A. (2010). Crowdsourcing as a business model, paper presented at $23^{\text {rd }}$ Bled eConference, Bled, Slovenia, 20-23 Jun

WAS (2019). Digital 2019, We Are Social, Singapore

WCED (1987). Our common future. Oxford, UK: Oxford University Press.

Wind, Y., \& Rangaswamy, A. (2001). Customerization: The next revolution in mass customization. Journal of Interactive Marketing, 15(1), 13-32.

Wirtz, B. W., Schilke, O., \& Ullrich, S. (2010). Strategic development of business models: Implications of the Web 2.0 for creating value on the Internet. Long Range Planning, 43, 272-290.

WP (2019). Facebook, Wikipedia https://en.wikipedia.org/wiki/Facebook

\section{AUTHOR BIOGRAPHY}

Richard Heeks is Chair in Development Informatics at the Global Development Institute, University of Manchester; and Director of the Centre for Development Informatics (http://www.cdi.manchester.ac.uk). He has been consulting and researching on informatics and development for more than 30 years. His book publications include India's Software Industry (1996), Reinventing Government in the Information Age (1999), Implementing and Managing eGovernment (2006), ICTs, Climate Change and Development (2012) and Information and Communication Technology for Development (2018). His research interests are data-intensive development, e-resilience and e-sustainability, digital politics, and the digital economy in developing countries. He has a PhD in Indian IT industry development, directs the MSc programme in ICTs for Development, and runs the ICT for Development blog: http://ict4dblog.wordpress.com.

How to cite this article: Heeks R. ICT4D 3.0? Part 1-The components of an emerging "digital-for-development" paradigm. E J Info Sys Dev Countries. 2020;e12124. https://doi.org/10.1002/isd2.12124 